\title{
Hazards of La Fortuna District, Alajuela, Costa Rica
}

\author{
Juan Carlos Robles and Mario Fernández Arce
}

\section{ABSTRACT}

In this paper we examine the characteristic and distribution of natural and man-made hazards in the District La Fortuna, Costa Rica, and show a Hazards Density Map. There are deadly hazards in the territory and both vulnerability and risk have increased, which demands actions to prevent disasters. Our interest is to provide useful results to improve the risk management in the district. We collected information available in scientific papers, technical reports, thesis, and Press releases and used the method Hazard Density Index to produce the Hazard Density Map. The findings point to a concentration of threats in in North of the district and confirm that the main hazard in the studied area is the volcanic eruption.

Keywords: Hazards, Density Index, Volcánic Hazard, Sísmic Hazard, Floods.

Published Online: December 18, 2020

ISSN: $2684-446 \mathrm{X}$

DOI : $10.24018 /$ ejgeo.2020.1.6.61

\section{Juan Carlos Robles}

(e-mail: juank17@yahoo.es)

Mario Fernández Arce*

Escuela de Geografía, Universidad de Costa Rica, Costa Rica.

(e-mail: mario.fernandezarce ${ }^{\circledR}$ ucr.ac.cr)

*Corresponding Author

\section{INTRODUCTION}

This paper focuses on the characterization and distribution of natural and anthropic hazards of the District La Fortuna (Fig. 1), aiming to identify and show the hazardous sites. The work includes a Hazard Density Index [1]-[5] and its correspondent map.

In the studied area there is an active and very young volcano that violently erupted in the recent past (1968), causing death and destruction. There are also nearby seismic sources that have generated relevant and killing earthquakes, large rivers whose overflows invade the low relief frequently and four gas stations with potential technological danger. Exposure to such hazards has increased because the
Arenal volcano strongly attract tourists and, therefore, tourism and touristic activities have increased considerably in La Fortuna. In consequence, both the vulnerability and the risk has been growing over time.

Processes such as urbanization, environmental degradation and climate change can influence the location, occurrence and intensity of natural hazards and be risk drivers. Therefore, threats and their spatial distribution should be investigated to find out the hazardous areas and makes easier the assessment and proper management of the risk. The purpose of this article is to briefly describe the threats and show their spatial distribution to improve the risk management.

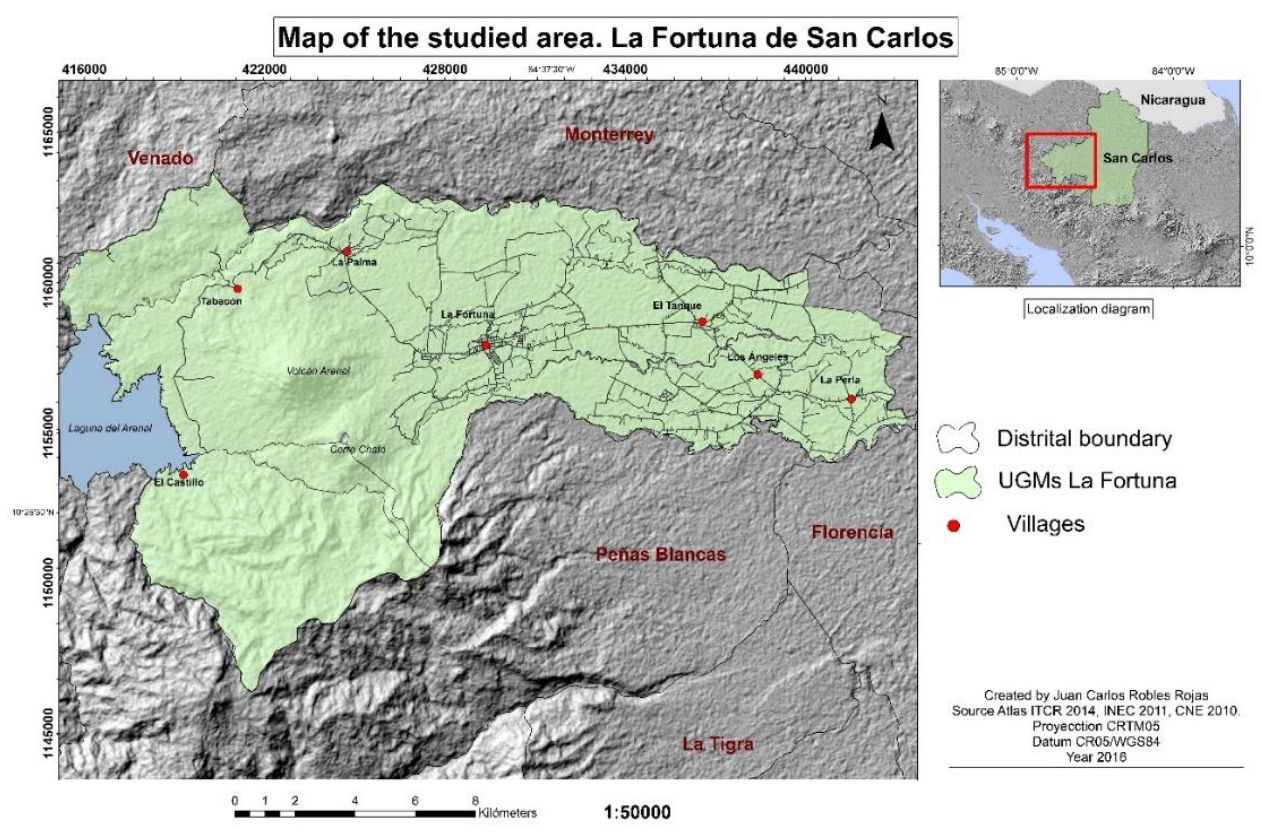

Fig. 1. Map of the studied area. 
A systematic bibliographical review was carried out to extract written information on hazard published in scientific articles of books, journals, magazines, and electronic websites. The bibliographic research also included mass media, mainly newspapers. Such activity was complemented with field surveys to know the extends of hazards and the critical sites. A Hazards Density Index was calculated by assigning values to each hazard in the 151 Minimal Geostatistical Units (MGU) of La Fortuna and the resulting scores are graphically display shown in a map.

The studied area is exposed to geological, hydrometeorological and potential technological hazards, specifically volcanic eruptions, floods, earthquake, and possibly gas station explosions. Results suggest that the highest hazards density is at the base of the northern flank of Arenal Volcano, which includes the communities located along Arenal Lake.

\section{METHODOLOGY}

Existing and available information about hazards was collected, organized, and reviewed to determine what types of hazards were present and which human settlements may be exposed or potentially exposed. Information available included scientific papers, technical reports, thesis and Press releases. Natural and technological incidents provided a clear indication of where hazards exist. By investigating incidents and reports, we identified hazards that are likely to cause future harm. Consulted sources include books, journals, newspapers, and magazines that contain original research or refer to research studies.

Field surveys was another method used to complement the process of primary data collection. Field work allowed us to better evaluate the impact of hazards. We conducted a field survey to get data on hazards and recognize areas affected by floods, lava flows, pyroclastic flows, and seismic events. Interviews to local leaders were a useful way to make a clear picture of the hazards extend and impact and know which would be the areas exposed to hazards.

We used the explosive efficiency factor of gas and gasoline, calculated by the Mexican Geological Survey (MGS) [6], to know the radius of maximum, medium and minimum danger associated to explosions in gas stations. To evaluate the scope of incidents at gas stations, the research group made an estimate [5], based on a linearity and proportionality relationship between the data from the La Fortuna stations and the results obtained by the MGS.

A Hazards Density Index was calculated by assigning a value between 0 and 1 to the hazards in each MGU. For this study, specific weights were set to such values, according to the frequency and intensities of the striking events. According to [7], the frequency is inversely proportional to the intensity or impact. Weighted scores were summed and divided by the total number of hazards to obtain an index of 6-categories.

\section{RESULTS}

\section{A. Volcanic Hazard}

Arenal is a symmetrical volcanic cone formed $7 \mathrm{ka}$ ago located in La Fortuna district. It is especially dangerous because of its relatively frequent and sometimes strong eruptions. Probably, future events will affect human being, health, property, agriculture, and the general economic welfare over an abroad area in the surrounding. This young volcano continuously emitted lava flows from July 1968 to 2010 and its current activity consists of small, weak, and sporadic steam columns.

The last large eruption of Arenal was in 1968 when the volcano violently erupted generating one or probably several pyroclastic flows. Those flows hit an area of $15 \mathrm{~km}^{2}$ and killed 78 people [8]. Since such deadly eruption the Arenal has emitted more than 100 lava flows and more than 60 pyroclastic events [10].

Regarding the risk management, Arenal is one of the few volcanoes that have a land use restrictions map [11]. At that volcanic area there is a ring of $5.5 \mathrm{~km}$ radius where volcanic bombs of up to $30 \mathrm{~cm}$ in diameter can fall. According to the map, lava flows descend the northwest and west slopes while lahars flow down by the northeast and east flanks. A second ring, larger than the first one, includes an area of falling bombs smaller than $6 \mathrm{~cm}$. There is also a series of thematic maps for each volcanic process of Arenal separately, based on the historical behavior of the volcano [12].

\section{B. Sísmic Hazard}

The western end of the studied area is bounded by the Graven of Arenal, a fault zone which includes the CoteArenal, Tilarán and Chiripa faults (Fig. 2). According to [16], the range of maximum ground pick acceleration is 301-400 gals in La Fortuna district, condition that demands a strict control on the building process. Earthquakes of CoteArenal fault are an important hazard for the human settlements of the Arenal Graven [13].

Historical seismicity along the Arenal graben report two major seismic events in the past. They are the 1911 Guatuso Earthquake and the 1973 Chiripa Earthquake. There is no exact location of the first one but the effects suggest an epicenter within the canton of Guatuso. According to the intensity map, the earthquake was located few km North of Arenal lake [13], in the Cote-Arenal fault-zone (Figure 2). The shock generated landslides, cracks on streets, fall of trees (the trees were rooted out) and destruction of small pour houses. Such event was strongly felt even in Central Costa Rica.

The Chiripa earthquake was located southward of Arenal lake, in the Chiripa fault zone [13]. Such event triggered several fluid, high-velocity debris flows [14] that killed 23 people. Some structures were damaged but did no collapsed. According to [15], windows and wall failed, objects felt down during the shock, transmission lines were damaged, and pipelines were broken. 


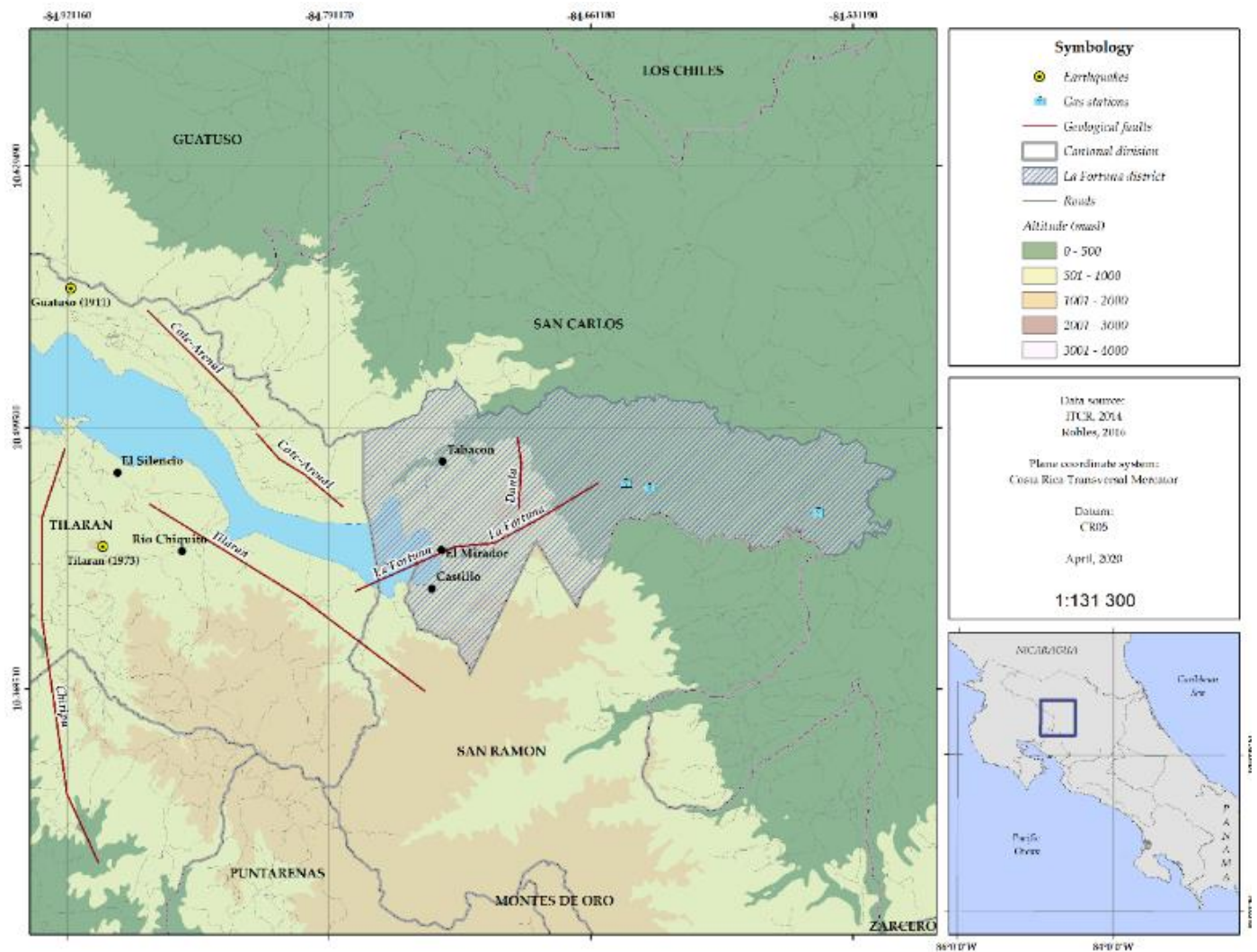

Fig. 2. Faulting and location of gas stations.

\section{Floods}

In the alluvial plane there are records of small floods since 1996. Those events are caused by rain associated to atmospheric perturbations and their main impact has been to the crops and economy. The heavy rain of 2000 caused obstructions of roads, landslides, and displacement of tens of people to temporal refugees. In addition, in the 20032007 period approximately 10000 persons were affected by river's overflows and it consequences like the damage to crops and livestock [17]. Few floods have been deadly as one in 2015 that killed one person.

\section{Technological Hazard}

Gas stations can pose significant hazards to people because diesel fuel or gasoline may drip from the nozzle onto the ground when people fill up their gas tanks and vapors may leak from the open gas tank into the air. This can lead to explosions because gasoline is highly flammable. In case of explosion, the expanding hot gases drive a shock wave into the surrounding material that can be destructive. In fact, one of these events happened in a Costa Rican gas station in 2006 and a person died as a result of the explosion.

In the district there are three gasoline stations (Fig. 2) that sells fuel and engine lubricants for motor vehicles: La Fortuna, La Cristalina and Los Angeles. Near some of them there are several commercial and touristic establishments, educational and health centers. During daylight many people work or walk near some gas expenditure what make them dangerous sites.

The radius of maximum danger due to possible shock waves at the La Fortuna, La Cristalina and Los Angeles gas stations are 11.42, 9.05 and 7.61 meters respectively. People of the three studied gasoline stations are very clear about the present risk, so they strictly adhere to the regulations.

\section{E. Hazards Density Index}

The Hazard density index is a measure of the hazard's distribution in each Minimum Geostatistics Units of the La Fortuna district. Some threats are more important than others when defining their relevance and scope or distribution in the territory and therefore, weighting is important to improve the accuracy of the survey estimates.

According to this work, there are volcanic eruptions, earthquakes, floods, and a technological hazard in the district. The most important one is the volcanic eruption because the Arenal can blast ash, lava, solid rocks, pyroclastic flows, and gases that can kill people and destroy property far away from the crater. Due to the killing eruptions and the short age of Arenal volcano, the relative contribution of the volcanic hazard to density index is 1 (the highest). The second in order of importance is the flood whose frequency is likely in periods of 5 and 10 years, according to key informants. Considering such information, we assigned a weight of 0.8 to the flood.

The weight for the seismic hazard is 0.6 since the moderate magnitude and medium intensity of the striking earthquakes. The degree and extent of damage caused by the earthquakes in the district is few and quite occasional. Recent Costa Rican events like the 2009 Cinchona earthquake and 1912 Nicoya earthquake caused few damages in the zone.

A weight value of 0.2 were assigned to the technological hazard because the incidents in gasoline stations are extremely scarce in La Fortuna. 
Fig. 3 shows the distribution of the Hazard Density Index in the district. According to the map, the main concentration of hazards (value indicator 0.8) is at the northern area of the district, where people and the infrastructure can be hit by volcanic eruptions, flood, and moderate magnitude earthquakes. The second highest category covers a small area near La Fortuna village where the index value is 0.60 and is due to the impact of eruption, earthquakes, and explosions in gas stations.

The index value in most of the district (Center and West) is 0.53 . This area is mostly covered by the volcanic products like lava and pyroclastic flows of Arenal volcano. In addition, due to a series of faults (Fig. 2) such as Danta [18] and La Fortuna [19], this zone is seismically active. The material of the great 1968 Arenal eruption descended by the western flank and affected the communities of Tabacón, Pueblo Nuevo and El Castillo, killing 78 people. All deaths took place between Tabacón and El Castillo. In Pueblo Nuevo, a community that was located between Tabacón and El Castillo, there was great destruction [20]. Such town was relocated due to the construction of the reservoir for hydroelectric power production.

The areas of the district with an index value equal to 0.46 are in the eastern side of La Fortuna, where there are floods. To the east of the district, where a single hazard was identified, the Hazard Density Index is 0.20 .

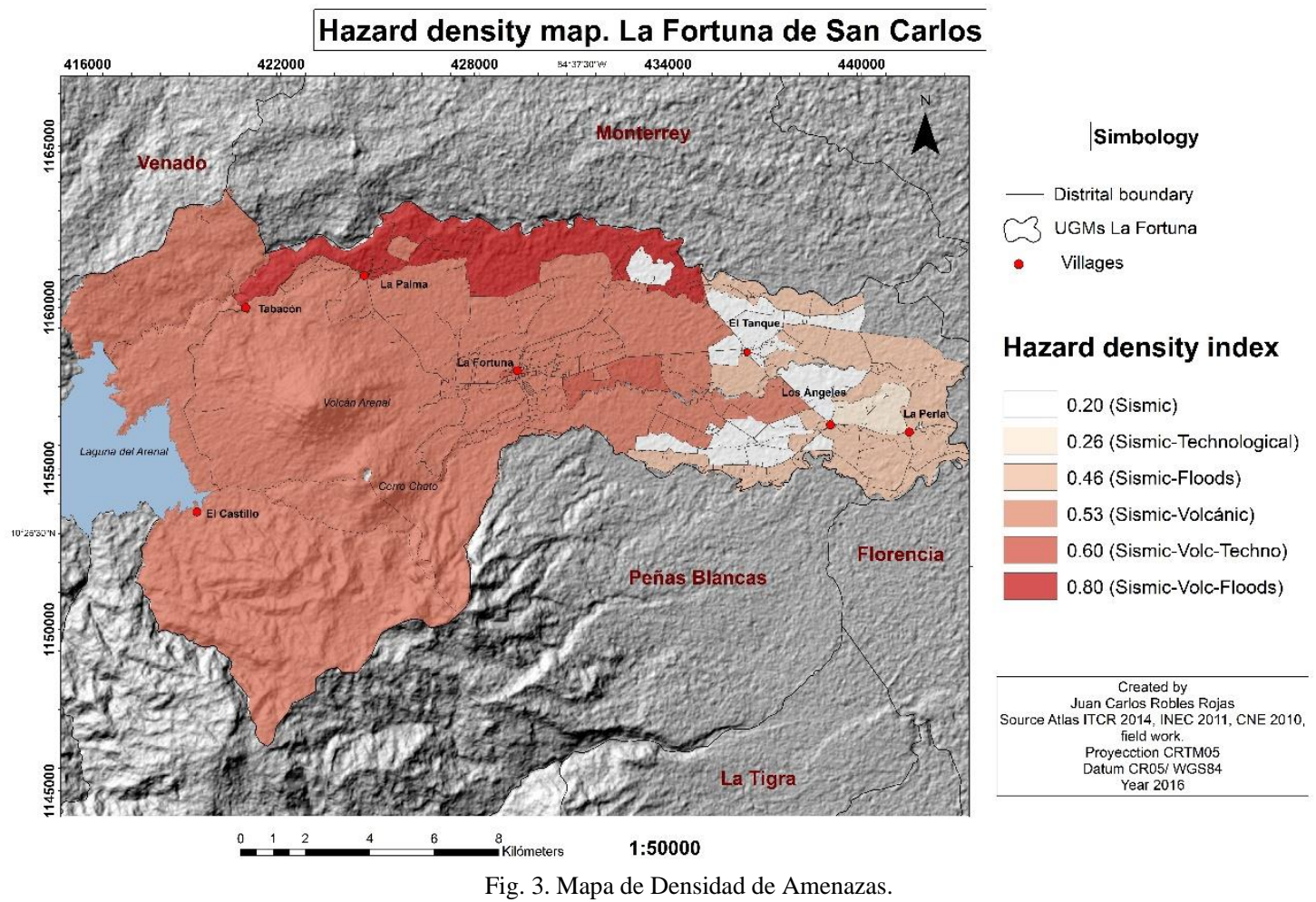

\section{CONCLUSIONS}

The hazards identified in La Fortuna district are volcanic eruptions, floods, earthquakes, and Incidents in gas stations. Of all, the most destructive so far has been the volcanic eruption which has caused deaths.

The highest hazard density index (index value 0.8 ) is in the northern area of the district where people and structures can be struck by flood, Plinian-type eruptions, and earthquakes.

Most of the area has an index value of 0,53 which is due to the impact of volcanic eruptions and earthquakes.

\section{ACKNOWLEDGEMENT}

Thanks to the University of Costa Rica for the supporting this research.

\section{REFERENCES}

[1] Collins et al., 2009: Vulnerability to environmental hazards in the Ciudad Juarez (Mexico)-El Paso (USA) metropolis: A model for spatial risk assessment in transnational context. Applied Geography 29 (2009) p. 448-461.

[2] Reyes, J., 2012: Determinación del Riesgo de Desastres en el cantón Santo Domingo de Heredia mediante sistemas de información geográfica. Tesis de Maestría, Universidad de Costa Rica, 101 pgs.

[3] Reyes, J., Fernández, M., Grinesky, S., Collins, T., 2014a: Natura Hazards in Santo Domingo de Heredia, Costa Rica, Central América Natural Science. Vol.6, No.3, 121-129.

[4] Reyes, J., Fernández, M., Grinesky, S., Collins, T., 2014b: Spatial Analysis of Disaster Risk in Santo Domingo De Heredia, Costa Rica, Central America. Journal of Geography and Geology, 6(3): 123-132. doi:10.5539/jgg.v6n3p123, http://dx.doi.org/10.5539/jgg.v6n3p123.

[5] Robles, J., 2016: Análisis geoespacial de amenazas y vulnerabilidades en el distrito La Fortuna de San Carlos, Costa Rica, 107 pgs.

[6] Servicio Geológico Mexicano (SGM, 2011): Atlas de riesgos del estado de Tamaulipas, Municipio de Victoria. Victoria: Servicio Geológico de México.

[7] Yamin, L., Ghesquiere, F., Cardona, O., \& Ordaz, M., 2013 Modelación probabilistica para la gestión del riesgo de desastre. Bogotá, Colombia: Universidad de Los Andes. 
[8] Alvarado, G., 2008: Los Volcanes de Costa Rica: geología, historia, riqueza natural y su gente. San José: 3ra Edición, San José, Costa Rica, EUNED, 386 pgs.

[9] Soto, G., Alvarado, G., 2006: Eruptive history of Arenal Volcano, Costa Rica, 7ka to the present. In Gill, J., Reagan, M., Tepley, F., y Malavassi, E., (eds), Arenal volcano special volume, Journal of Vulcanology and Geothermal Research 157(1-3): 254-269.

[10] Chavarría, O., 2005: La actividad volcánica del Arenal como fuente de desarrollo turistico y vulnerabilidad socioeconómica: una visión a partir de la percepción(Tesis de Licenciatura). Universidad de Costa Rica, Costa Rica.

[11] Comisión Nacional de Emergencias (CNE, 2004): Restricción al uso del suelo en áreas bajo amenaza volcánica: El Caso del Arenal. 14 pgs.

[12] Soto, G., Sjobohm, L, 2005: Sobre el mapeo de riesgos volcánicos de Arenal (Costa Rica) como una herramienta para la planificación del uso del suelo y la mitigación de desastres. Seminario de ingeniería estrutural y sismica. San José, Costa Rica, 26.

[13] Camacho, J., 2015: Caracterización Geofísica y Neotectónica de la Falla Cote, Costa Rica. Tesis de Licenciatura, Escuela de Geología, Universidad de Costa Rica, 158 pgs.

[14] Plafker G.,1973: Field reconnaissance of the effects of the earthquake of april, 1973, near Laguna de Arenal, Costa Rica. Informe interno Servicio Geológico de los Estados Unidos (USGS), 19 pags.

[15] RSN, 2020: Red Sismológica Nacional de la Universidad de Costa Rica. Sismo de Tilarán http://www.rsn.ucr.ac.cr/index.php/es/sismologia/sismoshistoricos/26-sismologia/sismos-historicos/3227-sismo-de-tilaran-13de-abril-de-1973.

[16] Benito, et. Al., 2012: A new evaluation of seismic hazard for the America Central Region. Bulletin of the Seismological Society of America, Vol. 102, No. 2, pp. 504-523, April 2012.

[17] Comisión Nacional de Emergencias (CNE, 2012): Histórico de desastres en Costa Rica. Febrero 1723- Setiembre 2012. 50 pgs.

[18] Alvarado, G., 2009: Geología de la Hoja La Fortuna, Alajuela, Costa Rica. Revista Geológica de América Central, 41: 117-122, ISSN 0256-7024.

[19] Taylor, W., 2014: La Sismicidad del 2013 en los Alrededores de los Proyectos de Generación Eléctrica ARCOSA y TEJONA (Guanacaste). OSIVAM-ICE, Informe Interno, 15 pgs.

[20] Alvarado, G., 2011: Los Volcanes de Costa Rica: geología, historia riqueza natural y su gente. 1 Reimpresión de la 3ra edición, San José, Costa Rica, EUNED, 335 pgs. 